\title{
HIPERTROFIA POLITYKI PAMIĘCI W III RP I JEJ KONSEKWENCJE OD ROKU 2015
}

\section{Tomasz Stryjek*}

\begin{abstract}
Abstrakt
Autor analizuje antagonizujące konsekwencje prowadzonej przez PiS polityki pamięci w stosunkach z Izraelem, Ukrainą, Niemcami, Rosją i międzynarodową opinią publiczną. Wskazuje na narastanie sporu wewnętrznego o prawomocność ustroju III RP po przełomie 1989 r. Sądzi, iż polityka pamięci jest adresowana głównie do partnerów zagranicznych, jednak osiąga skuteczność jedynie w polityce wewnętrznej w postaci konsolidacji elektoratu ugrupowań tradycjonalistycznych i nacjonalistycznych. Wiąże hipertrofię polityki pamięci z odchodzeniem od demokracji liberalnej w kierunku rządów jednostek o silnym autorytecie, wskazując na trzy przypadki poza Polską: Rosję, Węgry i Serbię.
\end{abstract}

Słowa kluczowe: polityka pamięci, polityka tożsamości, historiografia dziejów Polski XX w., Instytut Pamięci Narodowej, święta państwowe, dni pamięci, Europa Środkowa i Wschodnia

\section{HYPERTROPHY OF MEMORY POLICY IN THE THIRD POLISH REPUBLIC AND ITS CONSEQUENCES FROM 2015 TO PRESENT}

\section{Abstract}

The author analyzes the antagonistic consequences of the remembrance policy pursued by the Law and Justice Party in relations with Israel, Ukraine, Germany, Russia and international public opinion. He points to the growing internal dispute over the legitimacy of the system of the Third Polish Republic after the turn of 1989. The author believes that the policy of memory is addressed mainly to foreign partners, but achieves effectiveness only in internal politics in the form of consolidation of the electorate of traditionalist and nationalist groups. Tha author binds the hypertrophy of the remembrance policy with a departure from liberal democracy towards the rule of individuals with strong authority, pointing to three cases outside of Poland: Russia, Hungary and Serbia.

Keywords: memory policy, policy of identity, historiography od Poland in $20^{\text {th }}$ century, Institute of National Remembrance, state holidays, Eastern and Central Europe

*Dr hab. Tomasz Stryjek, Collegium Civitas, ISP PAN, tstryjek@wp.pl. 
Drugie rządy Prawa i Sprawiedliwości w Polsce od listopada 2015 roku przyniosły ze sobą tak silną dyskredytację polityki pamięci, że po ponad dwu latach trudno sobie wyobrazić, aby w przypadku odsunięcia tej partii od władzy przez siły centrowe i/lub lewicowe rządzący nadal uważali kształtowanie zunifikowanej pamięci zbiorowej za powinność państwa. Lider Platformy Obywatelskiej, Grzegorz Schetyna, już w październiku 2016 roku zapowiedział likwidację Instytutu Pamięci Narodowej i zwrócenie jego kompetencji tym instytucjom, od których zostały przejęte. Stanowi to przełom w historii sił politycznych III RP wywodzących się od demokratycznej opozycji sprzed roku 1989. Wszak w tymże roku wszystkie ich poprzedniczki w parlamencie (AWS, UW, KLD) zgodnie zagłosowały za powołaniem takiej instytucji. W przypadku PO ta zapowiedź nie oznacza jeszcze całkowitego porzucenia polityki pamięci przez państwo, lecz jej reorientację i zmniejszenie znaczenia. Natomiast „opcji zerowej” w tej kwestii można się spodziewać po ugrupowaniach lewicowych, u których „zbrzydzenie” upartyjnieniem obrazów przeszłości pod rządami prawicy sięgnęło zenitu.

Na początku roku 2018 nadmierne przywiązywanie wagi do pamięci narodowej oraz dążenie do osiągnięcia jednoznaczności w ocenie przeszłości przez PiS i Kukiz'15 doprowadziło do tego, że z jednej strony spory historyczne były już rozstrzygane na sali sądowej, z drugiej - władze państwa skłóciły się z ważnymi partnerami zagranicznymi. Jakkolwiek nie wszystkie z tych konfliktów były przez prawicę, czy wyłącznie przez stronę polską zawinione, a niektóre ciągnęły się już od ponad dekady, to jednak wszystkie zostały od roku 2015 przynajmniej zaognione. Partia rządząca nie liczyła się z tym, że polityka jest sztuką osiągania możliwego. Jeśli jest oparta wyłącznie na jednostronnie przyjętych kryteriach, jej przedmiot nie podlega negocjacjom oraz nie towarzyszy jej oferta korzyści dla partnera, może być skuteczna jedynie przy bardzo dużej przewadze potencjału. Gdy tej przewagi nie ma - a jak się w po- 
przedniej dekadzie okazało - Polska nie miała jej dość nawet w stosunku do Litwy, nie wspominając o Ukrainie czy Rosji - w końcu taka polityka staje się śmieszna.

W istocie w polityce władz państwa od roku 2015 mniej chodziło o sprawiedliwość wobec uczestników wydarzeń z lat 1939-1989, bardziej zaś o „godność” liderów partii rządzącej, którym jako reprezentującym Polskę na arenie międzynarodowej jakoby nie okazywano szacunku odpowiedniego do jej siły i znaczenia. W tej kwestii nie ma dużej różnicy między obecnymi władzami Polski i Rosji, które skądinąd mienią się znajdować po przeciwnych stronach w polityce międzynarodowej. Jednak, podobnie jak w Rosji, żądanie szacunku dla Polski od zagranicy jest adresowane przede wszystkim do własnej opinii publicznej. Wprowadzanie kwestii historyczno-symbolicznych do celów polityki zagranicznej nie służy tej ostatniej, lecz konsolidacji elektoratu partyjnego w polityce wewnętrznej ${ }^{1}$.

Zjawisko, które charakteryzuję w tym tekście pod nazwą hipertrofii polityki pamięci, występuje obecnie w całej Europie Środkowej i Wschodniej. Ma trzy cechy szczególne. Po pierwsze, wybór i nadanie strategicznego znaczenia takim celom, za których osiągnięcie trzeba by zapłacić tak wysokie koszty, że dla demokratycznej opinii publicznej (gdyby była ich świadoma), byłoby to nie do przyjęcia. Jeśli bowiem uważa się, że „godności” nie można negocjować, to wywołuje się u partnera takie samo przekonanie, zatem ostatecznie jego ustępstwo można uzyskać jedynie przez wojnę i okupację, albo przez ofertę korzyści na wielką skalę. Jednocześnie własnemu społeczeństwu można nieustannie wmawiać, że na przeszkodzie osiągnięciu celu stoi wyłącznie zła wola drugiej strony, co zapewnia stałe źródło pozyskiwania głosów ludzi niezadowolonych.

Po drugie, przeznaczanie coraz większych środków budżetowych na działania historyczno-symboliczne, do czego opinia publiczna została

I O tym, że celem polityki pamięci (polityki historycznej) w Europie Środkowej i Wschodniej jest przede wszystkim wewnętrzna hegemonia ideologiczna, jako jeden z pierwszych pisał rosyjski historyk Aleksiej Miller (2012: 9-32). 
przyzwyczajona. Wprawdzie jej przychylność kończy się, gdy następuje parę lat regresu $\mathrm{PKB}$, co przydarzyło się większości państw w tym regionie w latach 2008-2009. Jednak wskutek różnych zbiegów okoliczności akurat Polska stała się wtedy „zieloną wyspą”, zatem w niej inwestycje w infrastrukturę polityki pamięci nawet wtedy nie ustały. W końcu po trzecie, odciąganie uwagi opinii publicznej od obecnych problemów i kierowanie jej w przeszłość, która jakoby charakteryzowała się wyższym stopniem wspólnotowości narodowej. W ten sposób wytwarza się iluzję obecnej więzi, aby powstrzymać rosnącą indywidualizację, którą nieubłaganie wymuszają przemiany cywilizacyjne.

Ale działania, których celem jest wzmacnianie „godności” z tytułu samej przynależności narodowej (swoją drogą, traktowanej jako przypisana i niezbywalna), nie kształtują postaw obywatelskich i nie rozwijają wrażliwości społecznej. No chyba że chodzi o działania tak powierzchowne, jak w Polsce pomoc „świąteczna” kombatantom II wojny światowej. Rzecz sama w sobie chwalebna, ale równie okazjonalna jak ofiarowanie datków na Wielką Orkiestrę Świątecznej Pomocy. Ponadto jej adresatów zostało już tak niewielu, że państwo radziłoby sobie z jej udzieleniem poprzez Urząd ds. Spraw Kombatantów i Osób Represjonowanych bez dodatkowych nakładów na politykę pamięci.

Polska doświadcza przerostu polityki pamięci w największym stopniu wśród państw Europy Środkowej i Wschodniej. Jest pionierką rozwiązań instytucjonalnych oraz przeznacza na nie największe środki budżetowe. Niemniej skutki tego są takie, że o ile do roku 2014 w regionie państwem najbardziej podzielonym wewnętrznie co do oceny wydarzeń II wojny światowej i rządów komunistycznych była Ukraina, o tyle od roku 2015 pod tym względem wyprzedziła ją Polska.

Polska i Ukraina mają także współcześnie najwięcej otwartych pól konfliktu o pamięć II wojny światowej w stosunkach zewnętrznych. W Polsce władze promują jednostronne interpretacje wydarzeń z lat 
1939-1989, wychodząc z założenia, że umacnianie dumy narodowej stanowi warunek modernizacji gospodarki, wzrostu zamożności i zmniejszenia różnic społecznych.

Przekonanie, które ostatnio towarzyszy rządowi Mateusza Morawieckiego i Piotra Glińskiego, iż identyfikacja z tradycją sprzyja recepcji nowoczesnych technologii, jest wysoce dyskusyjne. Wprawdzie, odnosząc się do częstego argumentu polskiej prawicy, na podstawie doświadczeń Bawarii w okresie od II wojnie światowej (zob. Pilawski 2015), można uznać, iż przynajmniej nie szkodzi, to jednak ten przypadek nie stosuje się do Polski od roku 2015. W polityce pamięci rządów CSU w Monachium od roku 1949 szło jedynie o zachowanie konserwatywnego (katolickomonarchicznego) kolorytu historycznego największego landu w Niemczech. Natomiast PiS-owi dziś chodzi o objęcie przez Polskę roli moralnopolitycznego przywódcy całego regionu państw postkomunistycznych i zajęcie w ten sposób miejsca w Europie równorzędnego z Niemcami i Francją. Polityka pamięci polskiej prawicy, wypychając w „niepamięć” to, co w przeszłości było kontrowersyjne, rodzi skutki przede wszystkim nie konsolidujące, lecz antagonizujące. Zajmę się ich naświetleniem w wymiarze wewnętrznym i międzynarodowym.

W III RP do roku 2015

Ponieważ współczesny obóz rządzący wychodzi od bezpardonowej krytyki poprzedników, i ja wyjdę od spojrzenia na politykę pamięci do jesieni 2015 roku. Konflikt o ocenę wydarzeń II wojny światowej i epoki komunizmu poróżnił prawicę z innymi uczestnikami polskiej polityki już w latach 2002-2005, tj. w okresie prezydentury Lecha Kaczyńskiego w Warszawie, nagłośnienia projektu budowy IV RP i próby uczynienia mitem założycielskim tej ostatniej heroicznej pamięci o powstaniu warszawskim. 
To wtedy wskutek publicystyki zwolenników tych inicjatyw w polskim dyskursie publicznym nastąpiła recepcja terminu „polityka pamięci (polityka historyczna)" w znaczeniu wszystkich form oddziaływania aktorów politycznych na rzecz kształtowania tożsamości zbiorowej za pomocą obrazów przeszłości. Termin ten przyjęto z Niemiec. O tyle zgodnie z pierwowzorem, że polityka pamięci zaczęła być uważana za tak samo uprawnioną funkcję państwa, jak polityka socjalna czy edukacyjna ${ }^{2}$, o tyle inaczej, że zawężono ją do działalności władz, kwestionując prawo do jej prowadzenia przez opozycję i w ogóle inne podmioty. Argumentowano, że trzeba „zwrócić” historię ludziom, bowiem zajmowanie się nią zostało zmonopolizowane przez profesjonalistów i elity. Przekonywano, że obrona godności narodu jest kwestią racji stanu. Pod hasłem demokratyzacji, postępującej wraz z rozwojem nowych mediów, utrzymywano, że proponowana zmiana myślenia o państwie, przeszłości i patriotyzmie wyraża najszersze oczekiwania społeczne (Pamięć $i$ odpowiedzialność 2005).

Utworzenie muzeum o walce podjętej w stolicy w roku 1944 było hołdem, który należało złożyć pokoleniu Polski Podziemnej. Jednak realizacja projektu muzeum została związana z drogą kandydata prawicy od warszawskiego ratusza do Pałacu Prezydenckiego. M.in. przez to od początku inicjatywa miała wielu przeciwników, co zaciążyło na wydźwięku wystawy, przyczyniając się do wyeliminowania z niej dyskusji nad pytaniem, czy dla wybuchu powstania była jakakolwiek alternatywa (Krzemiński, Thiriet 2015: 620-628).

Pierwsze rządy PiS (2005-2007) pogłębiły także kryzys w stosunkach z Rosją, aczkolwiek na tym odcinku zaczął się on już wskutek interwencji poprzednich władz w przebieg pomarańczowej rewolucji na Ukrainie w roku 2004.

\footnotetext{
2 Niemieckie rozumienie terminu ukształtowane w latach 90. zeszłego wieku (zob. Wolfrum 1999; WolffPowęska 2011: 61-74).
} 
Następnie, przez osiem lat rządów PO, władze Polski prowadziły politykę pamięci oddającą centrowy charakter tej partii oraz zorientowaną na zawieranie porozumień z partnerami wewnętrznymi i zewnętrznymi. One także traktowały upowszechnianie pewnych interpretacji przeszłości jako strategiczne zadanie państwa. Jednak w latach 2007-2015, pomimo zwiększenia środków na politykę pamięci, nie można było jeszcze mówić o jej hipertrofii. Po pierwsze, władze nie dążyły do „unikalizacji” dziejów Polski na tle europejskim, lecz przeciwnie starały się o ich „normalizację", wydobywając z nich to, co stanowiło regionalną egzemplifikację szerszych tendencji. Po drugie, PO nie zakładała, że internalizacja mitów historii narodowej poprzez edukację oraz uczestnictwo obywateli w rytuałach rocznicowych stanowi warunek „odbudowy” więzi społecznych, czy wręcz przetrwania państwa. Podczas gdy właśnie ta idea przyświecała PiS, gdy w latach 2015-2017 zdecydował się odwrócić kierunek przemian w oświacie realizowanych od roku 1999 i wprowadził nową strukturę szkół oraz nowe programy nauczania.

W latach 2010-2015 władze, mając na uwadze ustalenia ekspertów, stosunki z Rosją oraz własną modernizacyjną narrację związaną z inwestowaniem w Polsce dużych środków europejskich, starały się przeciwstawiać w przestrzeni publicznej martyrologizacji katastrofy smoleńskiej jako porównywalnego z mordem katyńskim aktu antypolskiej polityki imperium, do czego w istocie sprowadza się teoria zamachu. Wobec Niemiec prowadziły politykę dwutorową. $Z$ jednej strony wyrażały zgodę na tylko takie upamiętnienie wypędzonych w Berlinie, które ukazywałoby ich jako ofiarę kolejnego aktu serii czystek etnicznych w Europie rozpętanych przez III Rzeszę, a nie aktu jedynego czy wyjątkowego, czego oczekiwali najbardziej zainteresowani. Z drugiej - realizowały projekt Muzeum II Wojny Światowej w Gdańsku, ukazujący m.in. niemieckie zbrodnie oraz polską konspirację i walkę jako działania, każde w swojej kategorii, bardzo zaawansowane, ale z wyjątkiem obozów Zagłady nie 
unikalne względem tego, co mniej lub bardziej działo się na większości terytoriów okupowanych na wschód od Niemiec.

Wobec Izraela i międzynarodowej opinii kształtowanej przez organizacje ochrony pamięci Holocaustu podtrzymywały stanowisko państwa z roku 2001 (współtworzone m.in. przez ówczesnego ministra sprawiedliwości, Lecha Kaczyńskiego), iż pogrom jedwabnieński i inne działania antyżydowskie z czasów wojny były dziełem Polaków, ale państwo polskie nie ponosi za nie odpowiedzialności. Zgadzały się natomiast, że współczesna Polska ponosi odpowiedzialność za zbadanie sprawstwa ich śmierci i upamiętnienie (Wokót Jedwabnego 2002).

Jednocześnie dokończyły, także popierany przez prezydenta Kaczyńskiego, projekt Muzeum Historii Żydów Polskich w Warszawie, ukazujący okres występowania antysemityzmu w Polsce jako jedynie kilkudziesięcioletni epizod $\mathrm{w}$ osiemsetletnich dziejach przeważnie pokojowego współżycia chrześcijan i judaistów na ziemiach państwa polskiego. W końcu wobec Ukrainy starały się krok po kroku doprowadzić do stwierdzenia przez jej władze większej odpowiedzialności UPA niż AK za masowe zbrodnie na Wołyniu i w Galicji Wschodniej w latach 19431944 bez negowania tego, że do roku 1939 „rachunek” nawzajem wyrządzonych sobie krzywd bardziej obciążał stronę polską.

Ogólnie biorąc, w bilansie polityki pamięci Polski w okresie rządów PO pozytywy przeważyły nad negatywami. Wielki sukces frekwencyjny odniosły oba wspomniane muzea. W obu bez ostentacji i sporów z przedstawicielami mniejszości narodowych oraz innymi państwami udało się pokazać, iż I oraz II Rzeczpospolita zachowały wielokulturowy charakter, unikając masowych represji na tle religijnym i narodowościowym. Wprawdzie w państwie polskim u schyłku okresu międzywojennego dały o sobie znać tendencje do przeprowadzenia czystek etnicznych, ale doszło do nich dopiero po katastrofie wojennej w latach 1945-1947 wobec Niemców, Ukraińców i Łemków. 
Ponadto do roku 2015 Polska utrzymała dobre stosunki z Niemcami, przyczyniając się do tego, że sprawa wypędzonych zeszła w nich na dalszy plan. Zachowała też przyjazne relacje z Izraelem. Umożliwiła rozwój badań w Polsce zarówno tym historykom II wojny światowej, którzy zajmują się przede wszystkim korzyściami odnoszonymi przez Polaków na Żydach (m.in. Grabowski 2011; Engelking 2011; Libionka 2017; Dalej jest noc. Losy Żydów w wybranych powiatach okupowanej Polski 2018), jak tym, którzy chcą głównie dokumentować i upamiętnić działalność Sprawiedliwych (m.in. Szpytma 2009). Polska historiografia wysunęła się na czoło badań nad stosunkiem do Zagłady ludności cywilnej oraz formacji ruchu oporu, wyprzedzając pozostałe państwa w Europie położone na wschód od Niemiec.

Jednocześnie niepowodzenia polityki pamięci Polski wobec Rosji oraz Ukrainy były spowodowane nie przez błędne założenia strony polskiej, lecz przez nieprzewidywalne zwroty sytuacji w Europie Wschodniej. W latach 2008-2011 władze Polski miały podstawy podzielać złudzenia całego Zachodu co do stopniowej demokratyzacji Rosji pod rządami prezydenta Miedwiediewa. Tym bardziej, że na początku jego kadencji podjęto inicjatywy na rzecz uhonorowania ofiar terroru stalinowskiego, a przy okazji siedemdziesiątej rocznicy wybuchu II wojny światowej premier Putin pokazał pragmatyczne podejście do kwestii historycznych, przyjeżdżając na międzynarodowe obchody do Gdańska i dyskutując publicznie z polską oceną konsekwencji paktu RibbentropMołotow (Putin 2009).

Co więcej, władze Polski zasadnie oceniły, że ogłoszona przed katastrofą smoleńską polityka „resetu” Stanów Zjednoczonych otwiera szansę na zbliżenie Rosji do Zachodu. Ostra rozprawa władz Rosji z „białym protestem" w Moskwie w zimie 2011/12, a tym bardziej uderzenie wojskowe na Ukrainę dwa lata później, były zaskoczeniem dla większości analityków stosunków międzynarodowych. Po rozpętaniu w latach 2014-2015 przez media rządowe w Rosji „antyfaszystowskiej” histerii medialnej 
wobec Ukrainy oraz oskarżeniu Polski i państw bałtyckich o współdziałanie ze Stanami Zjednoczonymi w rewizji ,jałtańskiej” oceny wyników II wojny światowej, porozumienie polsko-rosyjskie co do przeszłości przestało być osiągalne przed końcem rządów Putina.

Wybuch wojny w roku 2014 wpłynął też na ujednoznacznienie stosunku opinii publicznej Ukrainy do własnej historii nie tylko w okresie Imperium Rosyjskiego i ZSRR, ale także I oraz II Rzeczypospolitej. Odnośnie do Ukrainy jeszcze w styczniu 2010 roku, po kompromitacji prezydenta Juszczenki klęską wyborczą i zerwaniu przez niego niepisanego porozumienia z prezydentem Kaczyńskim co do niepopierania kultu Bandery, sternicy polskiej polityki mieli podstawy oczekiwać, iż zwycięski prezydent Janukowycz wykorzysta uczucie zawodu, jakiego doznała Polska i Europa, oceniając bilans rządów poprzednika, do wykreowania swego wizerunku jako pragmatycznego i otwartego lidera.

W ocenie prezydenta Komorowskiego „ceną” Ukrainy za dalsze stałe popieranie jej interesów w Brukseli w kierunku zawarcia traktatu stowarzyszeniowego i negocjacji o członkostwo w UE miało być zróżnicowanie oceny UPA przez napiętnowanie zbrodni wołyńskiej oraz umożliwienie upamiętnienia jej ofiar w miejscach ich śmierci, przy jednoczesnym zachowaniu pozytywnej narracji o niej odnośnie do oporu wobec ZSRR.

Niemniej pragmatyzm przypisywany Janukowyczowi okazał się być zdecydowanie bardziej krótkoterminowy niż się wydawało w Warszawie. Prezydent Ukrainy przedłożył utrzymanie się przy władzy na drugą kadencję i zbudowanie „zaplecza” oligarchicznego dla swych rządów nad strategiczne ściągnięcie inwestorów na Ukrainę i otwarcie rynku europejskiego dla jej towarów i pracowników. W roku 2013 nie wziął udziału z Komorowskim w Łucku w uroczystościach siedemdziesięciolecia początku rzezi. Następnie wycofał się ze swej polityki wobec UE i pod naciskiem finansowo-surowcowym Rosji w listopadzie 2013 roku za- 
wiesił podpisanie układu stowarzyszeniowego. Za swój koniunkturalizm, nie pragmatyzm, Janukowycz „zapłacił” utratą urzędu, ucieczką z kraju, w końcu zdradą Ukrainy.

Uderzenie Rosji na Ukrainę na początku 2014 r. spowodowało, że przed władzami w Kijowie stanęła kwestia już nie tyle dekomunizacji przestrzeni symbolicznej, ale także jej pełnej dekolonizacji. Jakkolwiek w obu przypadkach chodzi o usunięcie tego, co łączy Ukrainę z Rosją, potrzeba rekompensaty za brak własnego państwa do roku 1991, a następnie za brak jego suwerenności do 2014, rozpaliła emocje także w relacjach z Polską i Izraelem, które upomniały się o pamięć ofiar ukraińskiego ruchu nacjonalistycznego w czasie II wojny światowej. Postrzeganie Rosjan, Polaków i Izraelczyków przez ukraińską opinię publiczną jako narodów, których przodkowie odgrywali w przeszłości rolę „kolonizatorów”, ogranicza siłę wpływu polityki pamięci wobec tego państwa. Władze Ukrainy podtrzymują „godnościowe” stanowisko, którego rzecznikiem stał się UIPN, gdyż wobec konfliktu militarnego z Rosją ani Polska, ani Izrael, ani nawet cały Zachód nie mają im wiele do zaoferowania. Co więcej, efekty ich reform w ciągu ostatnich czterech lat są na tyle ograniczone, że taka polityka pamięci jest im potrzebna, aby skompensować utratę zaufania społecznego, tym bardziej, że można ją prowadzić jak najmniejszym kosztem (wobec Polski wystarczy nie zgadzać się na jej ocenę Wołynia).

Pozostaje tajemnicą, czy przyjęcie przez Radę Najwyższą 9 kwietnia 2015 roku ustawy chroniącej dobre imię organizacji „bojowników o niepodległość Ukrainy” w XX w., nie wyłączając z niej tych członków OUN i UPA, którzy popełnili zbrodnie przeciw ludzkości, niemal bezpośrednio po przemówieniu do izby prezydenta Komorowskiego, było gestem zamierzonym, czy wynikiem braku uwagi kierownictwa państwa. Ale nawet jeśli tylko tym drugim, to i tak nieuniknięcie koincydencji tych wydarzeń świadczy o spadku znaczenia Polski w polityce władz Ukrainy od roku 2014. 
„Powstanie z kolan” w ostatnich latach miało miejsce po obu stronach granicznego Bugu, niemniej w państwach o diametralnie różnej sytuacji gospodarczej, tożsamościowej i międzynarodowej. Na Ukrainie wiązało się z koniecznością obrony terytorium państwowego i potrzebą podtrzymania determinacji oporu. Ponadto nakłady per capita na politykę pamięci władz w Kijowie pozostały kilkadziesiąt razy mniejsze niż w Polsce od kilkunastu lat, a od kilku lat także niż w Rosji. Im więcej Ukraińcy wiedzą o Polsce i porównują wzrost standardów życia osiągnięty w niej od 1989 r. z sytuacją we własnym państwie, tym bardziej nie mogą się nadziwić, po co Polakom jeszcze symboliczne upokorzenie ludzi, którzy pomagają ich prężnej gospodarce uzupełnić niedobór siły roboczej.

Niestety, partie polskiej prawicy nie potrafią sobie wyobrazić, że dzieje rządów I oraz II Rzeczypospolitej na Kresach z zewnętrznej perspektywy mogą wyglądać jako panowanie typu kolonialnego (zob. Bakuła 2006: 11-33). Pozostają pod tak silnym wrażeniem własnej kreacji kultury polskiej jako protektorki idyllicznego współżycia wielu narodowości na Kresach, że każdy negatywny bilans rządów polskich na Ukrainie uznają albo za pozostałość sowietyzmu, albo wyraz etnicznego nacjonalizmu.

\section{Przerost instytucjonalny polityki pamięci}

W wymiarze infrastrukturalnym hipertrofia polityki pamięci w Polsce wyraża się, po pierwsze, w nasyceniu kalendarza świąt państwowych i dni pamięci symbolami martyrologiczno-heroicznymi z okresu 19181989, zwłaszcza 1939-1956. Wprawdzie w tym zakresie co do liczby nowych inicjatyw rządy prawicy od roku 2015 nie wyróżniają się w stosunku do większości rządów poprzednich, to jednak warto odnotować dalsze pogłębienie przez nie wspomnianej tendencji. Wcześniej mieliśmy już w kalendarzu: 
- Dzień Pamięci Ofiar Zbrodni Katyńskiej - 13 kwietnia (ustanowiony w roku 2007),

- Narodowy Dzień Pamięci Ofiar Niemieckich Nazistowskich Obozów Koncentracyjnych i Obozów Zagłady - 14 czerwca (2006),

- Dzień Pamięci o Zagładzie Romów i Sinti - 2 sierpnia (2011),

- Narodowy Dzień Pamięci Poznańskiego Czerwca 1956 roku - 28 czerwca (2006),

- Narodowy Dzień Pamięci Powstania Warszawskiego - 1 sierpnia (2009),

- Święto Wojska Polskiego - 15 sierpnia (1992),

- Dzień Weterana Walk o Niepodległość Rzeczypospolitej Polskiej - 1 września $(1997,2014)$,

- Dzień Sybiraka - 17 września (2013),

- Dzień Podziemnego Państwa Polskiego - 27 września (1998), w końcu

- Dzień Pamięci Ofiar Stanu Wojennego - 13 grudnia (2002).

Oprócz tego w Polsce oficjalnie obchodzi się Międzynarodowy Dzień Pamięci o Ofiarach Holocaustu - 27 stycznia (ONZ; 2005) oraz Europejski Dzień Pamięci Ofiar Stalinizmu i Nazizmu 23 sierpnia - (UE; 2008), zresztą ustanowiony z inicjatywy deputowanych do Parlamentu Europejskiego głównie z Polski i innych państw dotkniętych skutkami Paktu Ribbentrop - Mołotow3.

Od jesieni 2015 roku przede wszystkim nadano nową wymowę Narodowemu Dniu Pamięci „Żołnierzy Wyklętych”. Obecne władze uwagę skupiły się na uhonorowaniu dowódców, którzy od roku 1945 działali na własną rękę czy w ramach obozu narodowego, reprezentując postawę braku akceptacji dla jakichkolwiek zmian po wojnie i walkę zbrojną usque ad finem. W sposób charakterystyczny dla całej swojej polityki pamięci władze pominęły takie „niuanse” w biografii płk. Zygmunta

3 Pomijam tu daty w oficjalnym kalendarzu, które nie niosą ze sobą przede wszystkim przesłania heroicznomartyrologicznego: Święto Pracy - 1 maja, Święto Narodowe - 3 Maja, Dzień Wolności i Praw Obywatelskich - 4 czerwca (2013) oraz Dzień Solidarności i Wolności - 31 sierpnia (2005). 
Szendzielarza „Łupaszki”, jak dowodzenie w czerwcu 1944 roku na rozkaz komendanta Okręgu Wileńskiego rajdem 5 Wileńskiej Brygady AK, w czasie którego w Dubinkach i kilku innych wsiach litewskich zamordowano kilkadziesiąt osób cywilnych, „odpowiadając” na wcześniejsze zbrodnie policji litewskiej na Polakach (Rokicki 2015).

Wypromowanie na główny symbol Żołnierzy Wyklętych tego, skądinąd zasłużonego, oficera przyczyniło się do zdjęcia anatemy z innych dowódców, w przypadku których działalność niepodległościowa nie daje się już oddzielić od zbrodni na tle narodowościowym czy zwykłego bandytyzmu. W konsekwencji postępuje heroizacja także takich postaci, jak Józef Kuraś „Ogien” na Podhalu, Romuald Rajs „Bury” na Podlasiu czy Józef Zadzierski „Wołyniak” na Rzeszowszczyźnie, w której uczestniczą niektórzy pracownicy IPN. Przypadki mordowania przez ich oddziały w latach 1945-1946 cywilnych Żydów, Słowaków, Białorusinów i Ukraińców tłumaczy się tym, że ofiary służyły państwu komunistycznemu lub odwetem za zbrodnie na Polakach4.

Gwoli sprawiedliwości trzeba przyznać, iż obecne działania pod adresem tych postaci nie są nowe. Jednostronne spojrzenie na „Łupaszkę” trwa od pierwszej fali idealizacji pokolenia „wyklętych” w wydawnictwach drugiego obiegu w latach 80. (Fikus 1988). Z kolei ukształtowaniu pamięci o „Ogniu” na przełomie lat 80. i 90. przysłużył się taki autorytet pokolenia „Solidarności”, jak ks. prof. Józef Tischner.

Co więcej, do heroizacji tych dowódców przyczynił się Bronisław Komorowski w latach 9o. Zeszłego wieku jako minister obrony narodowej, a w latach 2010-2015 jako prezydent. To on doprowadził do ustanowienia Narodowego Dnia Żołnierzy „Wyklętych” w roku 2011. Niemniej, biorąc pod uwagę całość jego polityki, można wnioskować, iż bardziej chodziło o program oporu wobec komunizmu takich organizacji jak Zrzeszenie „Wolność i Niezawisłość”, a nie o beznadziejną już wtedy

4 Zob. m. in. promocję przez IPN filmu Ewy Szakalickiej o „Burym” - Podwójnie wyklęty (2017). 
walkę zbrojną, tym bardziej, że jej ofiarą padała czasem ludność cywilna ${ }^{5}$.

Do wymienionego katalogu czczenia aktów martyrologii i heroizmu Sejm obecnej kadencji dodał jeszcze dwie bardzo jednoznaczne pozycje. Na 11 lipca ustanowił Narodowy Dzień Pamięci Ofiar Ludobójstwa dokonanego przez nacjonalistów ukraińskich na obywatelach II Rzeczypospolitej Polskiej, a na 12 lipca Dzień Walki i Męczeństwa Wsi Polskiej. Pod koniec kadencji poprzedniej izby „przesunięto” też obchody zakończenia II wojny światowej z 9 na 8 maja, nazywając drugi z nich Narodowym Dniem Zwycięstwa (2015). Aktem tym słusznie „wyrównano” datę obchodów z państwami Europy Zachodniej i Środkowej, podczas gdy od roku 1945 w Polsce obowiązywała data „moskiewska”, symbolizująca podporządkowanie ZSRR ${ }^{6}$, aczkolwiek symbol ten pozostał martwy, jakim był od roku 1990.

Podsumowanie tego kalendarza prowadzi do wniosku, że w ciągu roku bez obchodów, które mają na celu utrwalić związek społeczeństwa z wydarzeniami z okresu 1918-1989 pozostają jedynie luty, październik i listopad. Jednak naprawdę czas wolny od pamięci o cierpieniu i walce ogranicza się tylko do lutego, gdyż są jeszcze dwa dni o nie tak jednoznacznej, ale zbliżonej wymowie: 16 października Dzień Papieża Jana Pawła II (2005) oraz 11 listopada Narodowe Święto Niepodległości (1937, 1989).

Po drugie, w Polsce mamy do czynienia z przerośniętą infrastrukturą instytucjonalną polityki pamięci, do czego obecny rząd przyłożył rękę bardziej niż którykolwiek wcześniej. Pomimo rozwoju podobnych instytucji także w innych państwach regionu, powołany jako pierwszy IPN pozostał instytucją niedoścignioną. Jedynie w Polsce ma on strukturę

\footnotetext{
5 Te działania Komorowskiego skłaniają do refleksji nad tym, jak łatwo w polityce pamięci „radykałowie” po objęciu władzy potrafią wykorzystać „infrastrukturę” stworzoną przez „umiarkowanych”. W związku z tym warto postawić problem, rzecz jasna, do rozważania w innym opracowaniu, jaka polityka pamięci państwa w Polsce eliminowałaby ryzyko takiej radykalizacji, jak nastąpiła od $2015 \mathrm{r}$.

${ }^{6}$ Podpisanie kapitulacji III Rzeszy w Berlinie wobec przedstawicieli koalicji wypadło w momencie, w którym w ZSRR było już po północy, zaś w Niemczech, Polsce i reszcie Europy przed północą z 8 na 9 maja $1945 \mathrm{r}$.
} 
oddziałową, obejmując poza centralą jedenaście oddziałów regionalnych oraz siedem delegatur, łącznie więcej niż liczba województw.

Zgodnie z intencjami ustawodawców z grudnia 1998 roku, Instytutowi nadano trzy obowiązki, tworząc trzy odpowiadające im piony:

1. prowadzenia badań naukowych i ich upowszechnienia,

2. przechowywania i udostępniania archiwów służb bezpieczeństwa oraz

3. ścigania zbrodni nazistowskich i komunistycznych, innych zbrodni wojennych i przeciw ludzkości (Komisja Ścigania Zbrodni przeciw Narodowi Polskiemu) (Ustawa o Instytucie Pamięci Narodowej - Komisji Ścigania Zbrodni przeciw Narodowi Polskiemu 1998; KoczwańskaKalita 2015, ss. 82-90; Dudek 2011).

Zgodnie z założeniami, za kadencji pierwszego prezesa w latach 20002005, IPN miał szanse stać się unikatową w skali światowej instytucją tzw. sprawiedliwości tranzycyjnej, opartej na zasadach ochrony praw człowieka. Przypomnijmy, że jej celem jest odbudowa praworządności, wspólnoty politycznej i zaufania do państwa w krajach, które przeszły przez dyktaturę i/lub wojnę poprzez zadośćuczynienie ofiarom, wymierzenie kary sprawcom, stworzenie nowej narracji o przeszłości, w końcu edukację o przeszłości celem prewencji zagrożeń dla demokracji (o Polce zob.: Transitional Justice in Eastern Europe and the Former Soviet Union. Reckoning with the Communist Past 2009: 76-101).

Nieszczęściem IPN okazała się być ustawowa zależność jego kierownictwa od układu sił w Sejmie, w związku z którą zmian w składzie rady /kolegium oraz na funkcji prezesa dokonywano po zakończeniu każdej ich kadencji w zależności od wpływu partii rządzącej. Już w latach 2005-2010 IPN zaczął przekształcać się w instytucję głównie zajmującą się kształtowaniem tożsamości narodowej, aczkolwiek proces ten powstrzymano w następnej kadencji jego władz (2011-2016).

Sprawiedliwość tranzycyjna ma z natury rzeczy charakter przejściowy, związany z okresem transformacji. Zgodnie z tą logiką działalność IPN, 
mierzona wielkością jego budżetu, powinna najpierw utrzymywać się na początkowym poziomie, lub nieco rosnąć wraz z rozpoznaniem skali potrzeb, ale następnie powinna maleć. Jednak w ciągu prawie dwudziestu lat jego funkcjonowania nastąpił wzrost wydatków w sumie o 100\%. O ile w pierwszych dwu pełnych latach działalności 2001-2002 wyniosły one po ok. $180 \mathrm{mln}$ zł, to w roku 2015 już $249 \mathrm{mln}$, dwa lata później 289 $\mathrm{mln}$, a na rok 2018, według uchwalonego budżetu, aż $363 \mathrm{mln}$ !

O tym, że Instytut nie zamierza redukować działalności, świadczy przeznaczenie części kosztów w roku 2018 na pozyskanie nowej siedziby dla centrali oraz rozwój infrastruktury oddziałów. Pod nowym kierownictwem od połowy 2016 roku IPN stał się przede wszystkim instytucją polityki tożsamościowej, czego wyrazem jest nie tylko włączenie się do działań, które władze nazywają walką z dyfamacją Polski na arenie międzynarodowej7, ale także realizacja szerokiego planu ekshumacji w Polsce „żołnierzy wyklętych” i innych ofiar z okresu 1944-1953, czemu towarzyszy intensywna akcja edukacyjna. Jednocześnie już od wielu lat liczba spraw o zbrodnie z okresu 1939-1953 zakończonych skierowaniem oskarżenia do sądu sięga jedynie kilkunastu rocznie (przy ponad stu prokuratorach).

Wydaje się, że ujawnienie w styczniu 2018 r. akcji IPN polegającej na sprawdzeniu, czy gdziekolwiek na świecie ukrywa się jeszcze ktokolwiek z ok. 1600 esesmanów służących w obozach zagłady, którzy nigdy nie byli ukarani, miało bardziej na celu zwrócenie uwagi międzynarodowej opinii publicznej na zbrodnie niemieckie w Polsce w związku z kampanią antydyfamacyjną rządu, niż postawienie przed sądem garstki ludzi ponad dziewięćdziesięcioletnich (Kozubal 2018).

Wygaszanie pionu śledczego IPN i przeniesienie części jego pracowników do prokuratury generalnej planowano już w związku z pracami

7 Pierwszym sygnałem była wypowiedź z 19 lipca 2016 r. Jarosława Szarka w czasie postępowania konkursowego na stanowisko prezesa przenosząca w całości odpowiedzialność za zbrodnię w Jedwabnem w roku 1941 z Polaków na Niemców. 
nad nową ustawą o tym organie ochrony prawa przed zmianą władz w roku 2015 (Uzasadnienie 2015).

Ustawą z 29 kwietnia 2016 roku zniesiono tryb powoływania prezesa IPN przewidujący istotny udział środowiska naukowego historyków na rzecz trybu oddającego wyłączną kontrolę nad tym procesem politykom, tj. większości w obu izbach parlamentu, które powołują siedmiu członków kolegium Instytutu, a następnie zatwierdzają kandydata wyłonionego przez to ciało, oraz prezydentowi, mianującemu dwu ostatnich członków kolegium. Rozszerzono zakres odpowiedzialności Instytutu o okres od objęcia przez bolszewików władzy w Rosji 8 listopada 1917 roku, podczas gdy dotychczas obejmował on jedynie okres od 1 września 1939 do 31 lipca 1990 roku. Dotychczasową strukturę Instytutu, oddającą jego cztery główne zadania (zgodnie z nowelizacją z 2006 r. do trzech pierwotnych biur dodano Biuro Lustracyjne), rozszerzono, tworząc Biuro Upamiętnienia Walk i Męczeństwa oraz Biuro Poszukiwań i Identyfikacji. Z drugiego z istniejących od początku pionów wyodrębniono Biuro Badań Historycznych i Biuro Edukacji Narodowej, tworząc ostatecznie aż siedem działów (Ustawa o zmianie ustawy o IPN - KŚZpNP oraz niektórych innych ustaw 2016).

Za poprzednich kadencji władz IPN prowadził badania nie tylko nad represjami i oporem, ale także kwestiami społecznymi w PRL. Nie obawiał się wydawać prac na tematy dzielące współczesną opinię publiczną (Moroz 2016). Jako taki nie odstawał od tendencji we współczesnej historiografii światowej (Jarska 2015; Płeć buntu. Kobiety w oporze społecznym $i$ opozycji $w$ Polsce $w$ latach 1944-1989 na tle porównawczym2014). Co więcej, poprzednie kierownictwa starały się „pytać” przedstawicieli polskiej uniwersyteckiej profesury humanistycznej, jak oceniają działalność instytucji, organizując co kilka lat konferencje na temat jej wizerunku i zadań (Pamięć i polityka historyczna. Doświadczenia Polski i jej sq̨siadów 2008; Bez taryfy ulgowej. Dorobek naukowy i edukacyjny Instytutu Pamięci Narodowej 200O-2010 2012). 
Pod nowymi rządami te rodzaje działań zostały porzucone. Koncentrując niemal wszystkie funkcje państwowej polityki pamięci w Polsce, IPN zbliżył się do ideału Orwellowskiego „ministerstwa pamięci”. Wraz z Ministerstwem Kultury i Dziedzictwa Narodowego stał się głównym zarządcą badań oraz upamiętnienia historii politycznej Polski XX wieku.

Jeśli idzie o infrastrukturę muzealną polityki pamięci, w okresie od roku 2015 również trwa kontynuowanie dotychczasowych projektów i rozpoczynanie kolejnych. Niektóre inicjatywy muzealne mają już ponad dziesięcioletnią historię, a nadal nie są ukończone. Należy do nich Muzeum Historii Polski, powołane jeszcze w roku 2006, w okresie pierwszych rządów PiS. Jego zespół dopiero w okresie premierostwa Ewy Kopacz zdołał przekonać rząd do sfinansowania budowy siedziby na Cytadeli w Warszawie. Wraz z nim powstaje tam siedziba Muzeum Wojska Polskiego, której jej rzeczywiście nie miało, „goszcząc” od wielu dziesięcioleci w gmachu Muzeum Narodowego. Z kolei Muzeum Józefa Piłsudskiego w Sulejówku jest owocem działań Fundacji Rodziny Marszałka, która otrzymała finansowanie od MKiDN w roku 2008 z perspektywą oddania gotowego projektu również w listopadzie 2018 roku.

Dodajmy, że w Polsce w ostatnich latach powstały lub powstają, m.in. przy wsparciu środków europejskich, także duże muzea o ambicjach ogólnopolskich tworzone przez samorządy. Tą drogą w roku 2015 w Gdyni doszło do otwarcia Muzeum Emigracji, a w Katowicach - nowej wystawy Muzeum Śląskiego. W roku 2010 w Krakowie otworzono wystawę na temat okupacji hitlerowskiej w Fabryce Emalia Oskara Schindlera (Oddział Muzeum Historycznego Miasta), a w Białymstoku utworzono Muzeum Pamięci Sybiru. Dużą inwestycją samorządowo-rządową, wyjątkowo wspieraną przez wszystkich prezydentów i premierów, zrealizowaną w latach 2007-2014, było Europejskie Centrum Solidarności w Gdańsku. Jedynie Muzeum PRL w Krakowie Nowej Hucie, założone jeszcze w roku 2008 nie doczekało się dotacji rządowej, która pozwoliłaby na stworzenie pełnowymiarowej wystawy stałej. 
Istnieją także inicjatywy dotyczące innych wydarzeń i zjawisk z okresu 1939-1989 pochodzące jeszcze z lat 9o. Zeszłego wieku, jak Muzeum Katyńskie w Warszawie (dział Muzeum Wojska Polskiego) czy Muzeum Armii Krajowej w Krakowie. Właściwie każda z tych inicjatyw z osobna miała niepodważalne argumenty, aby być zrealizowaną, podobnie jak muzea upamiętniające obozy zagłady w Polsce, których ekspozycje odnowiono (Auschwitz, Majdanek) lub utworzono niemal od podstaw w ostatniej dekadzie (Małkinia, Sobibór, Bełżec, Chełmno).

Jednak już przed rokiem 2015 można było zadać pytanie, czy duża skala upamiętnień o wymowie martyrologiczno-heroicznej nie okaże się przeciwskuteczna? Czy nie przyczyni się to zasklepienia i samych Polaków i cudzoziemców odwiedzających Polskę, w przekonaniu, iż polska identyfikacja ze wspólnotą sprowadza się do kultywowania „apokaliptycznych” doświadczeń z „wieku skrajności”? A może przeciwnie - odrzucenia takiej interpretacji historii (a wraz z nią i polskości) przez następne pokolenia?

Władze Polski od końca 2015 roku dodały do infrastruktury muzealnej już nie tak wiele, jednak znamienne jest, że główne ich działania mają na celu upamiętnienie polskiej „cywilizacji” na Wschodzie i walki z zagrożeniami nadchodzącymi z tego „kierunku”. I tak w grudniu 2017 roku MKiDN przychylił się do prośby władz Lublina o sfinansowanie zakupu Pałacu Lubomirskich w centrum miasta na Muzeum Ziem Wschodnich Dawnej RP (pierwotnie pod nazwą Muzeum Kresów). Nacisk położono na dwie inicjatywy związane z uczczeniem Żołnierzy Wyklętych. Pierwsze będzie poświęcone im oraz Więźniom Politycznym PRL-u powstaje w dawnym więzieniu Ministerstwa Bezpieczeństwa $\mathrm{Pu}$ blicznego na ulicy Rakowieckiej w Warszawie. Drugie będzie dotyczyć już wyłącznie powojennego oporu zbrojnego - ze wsparciem rządu budują je władze samorządowe Ostrołęki. W końcu w sierpniu 2017 roku Ministerstwo Obrony Narodowej zapowiedziało stworzenie w ciągu trzech lat dużego Muzeum Bitwy Warszawskiej oraz Parku Kulturowego - 
Wrota Bitwy Warszawskiej (oddział Muzeum Wojska Polskiego) w Ossowie pod Warszawą.

Biorąc pod uwagę istnienie silnego pionu badawczego IPN oraz działów badawczych $\mathrm{w}$ wielu wymienionych muzeach, liczne instytuty historyczne na uniwersytetach oraz w PAN, zastanawia to, w jakim celu władze utworzyły kolejne instytucje mające na celu dokumentowanie i upamiętnianie martyrologii i heroizmu Polaków. W maju 2016 roku powołano Ośrodek Badań nad Totalitaryzmami im. Witolda Pileckiego. Jeśli chodzi o patrona, bezwzględnie zasługuje on na bycie wzorem postaw pokolenia lat 30. i 40. zeszłego wieku, jednak otwarte pozostaje pytanie, czy powołanie tej instytucji było potrzebne. Zgodnie z jej misją większy nacisk zostanie położony na zbrodnie niemieckie niż sowieckie oraz na udostępnienie źródeł-relacji mówiących o nich badaczom zagranicznym (zob. Instytut Pileckiego). Najprawdopodobniej MKiDN chodzi m.in. o krytykę poglądu, popularnemu w Europie Zachodniej, iż stalinizm i w ogóle komunizm miał inne cechy strukturalne i konsekwencje niż reżimy Hitlera i Mussoliniego, zatem kategoria totalitaryzm jest niepotrzebna i utrzymuje się w dyskursie historycznym jako relikt amerykańskiej propagandy zimnowojennej czy element ideologicznej współczesnego dominacji neoliberalizmu (Žižek 2005: 8).

Jednak powstanie Ośrodka należy wiązać przede wszystkim z polityką antydyfamacyjną władz w tym przypadku opartą na działaniach pozytywnych, czyli promocji historii Polski, a nie negatywnych, tj. karaniu za mijanie się z faktami czy świadome pomówienia. Jeszcze bardziej dotyczy to Instytutu Solidarności i Męstwa, który Sejm powołał ustawą z 9 listopada 2017 roku, przyznając wysoki budżet $75 \mathrm{mln}$ zł. Ma on być przede wszystkim instytutem badawczym, a także dbającym o uhonorowanie osób w Polsce i zagranicą zasłużonych „w dziele pielęgnowania pamięci lub niesienia pomocy osobom narodowości polskiej lub obywatelom polskim innych narodowości będącym ofiarami zbrodni" 
masowych od 8 listopada 1917 do 31 lipca 1990 roku (Ustawa o Instytucie Solidarności i Męstwa 2017).

Celem wypełnienia drugiej z tych funkcji Sejm już wcześniej ustanowił nowe odznaczenia Krzyż Wschodni i Krzyż Zachodni, a wspomnianą ustawą dodał jeszcze Medal Virtus et Fraternitas. Upoważnił dyrektora Instytutu do wnioskowania o przyznanie dwu pierwszych z nich do ministra spraw zagranicznych, a ostatniego do prezydenta. Owocem działania tej instytucji może być m.in. odznaczenie Ukraińców, którzy w okresie II wojny światowej uratowali na Wołyniu i w Galicji Wschodniej od śmierci obywateli polskich różnych narodowości (ibidem). O takiej potrzebie w Urzędzie Prezydenta mówiono już przy okazji obchodów siedemdziesięciolecia rzezi wołyńskiej w roku 2013. Ówczesne zaniechania w tym zakresie „owocują” dziś nadmierną rozbudową instytucji, czemu, co gorsza, towarzyszy zalew publikacji o moralnej wyższości nie tylko uhonorowanych, ale całego narodu polskiego.

Na pytanie, dlaczego wykonywania zadań badawczych tych dwu instytucji nie miałby się także podjąć IPN, kierownictwo MKiDN daje do zrozumienia, że nie udźwignąłby ich. Ośrodek i Instytut z założenia mają być zwrócone ku zagranicy, intensywnie szkolą swych pracowników w zakresie języków obcych oraz będą przyznawały stypendia na korzystanie z polskich źródeł badaczom zagranicznym, zobowiązując ich do publikacji anglojęzycznych (Gawin: Instytut Solidarności i Męstwa wprowadzi polskie źródła do światowej historiografii 2018). Argument ten sam w sobie trudno podważyć, gdyż odnowi się on do rzeczywiście niskiego obecnie poziomu umiędzynarodowienia działalności badawczej IPN. Jednak dlaczego państwo nadal prowadzi politykę rozbudowy infrastruktury polskiej polityki pamięci, zamiast redukować te struktury, które się nie sprawdziły lub wyczerpały swą misję i w ich miejscach powoływać nowe? 
Antagonizujące konsekwencje krajowe i międzynarodowe

Od roku 2015 poważniejszym problemem niż wywołanie lub pogłębienie podziałów co do oceny przeszłości wewnątrz Polski i zagranicą jest wzrost nakładów na politykę pamięci. Chodzi tu o sześć kwestii.

Po pierwsze, o próbę odebrania Lechowi Wałęsie wiarygodności jego drogi życiowej jako osoby publicznej. Jakkolwiek w tej kwestii sam zainteresowany nie rozjaśnia w pełni wszystkich epizodów w swej biografii, czym ułatwia ataki przeciwnikom, to jednak dla zrozumienia źródeł takiego jego postępowania trzeba wziąć pod uwagę, iż stawką w tej walce nie jest ostateczne ustalenie, na czym polegały jego kontakty z SB $\mathrm{w}$ pierwszej połowie lat 70. Zeszłego wieku, lecz usunięcie go z grona ludzi zasłużonych w historii Polski oraz negatywna ocena okoliczności narodzin i pierwszych lat rządów III RP.

Polityka ta przede wszystkim antagonizuje polską opinię publiczną, jakkolwiek budzi także spore zdumienie za granicą. W latach 9o. Wałęsa wszedł do wąskiego grona nie więcej niż dziesięciu postaci kojarzonych z historią Polski na świecie. Próbując odebrać mu to miejsce na rzecz postaci także zasłużonych dla powstania niezależnych związków zawodowych w Gdańsku, jednak dla rozwoju sytuacji w Polsce w latach 19801995 drugorzędnych, PiS podważa nie tylko pozycję obecnej opozycji, podtrzymującej Wałęsę, ale także autorytet zagranicznych instytucji, które tego lidera doceniły. Wszak były prezydent jest jedynym laureatem Pokojowej Nagrody Nobla (1983) reprezentującym państwa Europy Środkowej i Wschodniej (oprócz Andrieja Sacharowa i Michaiła Gorbaczowa), a także jedynym politykiem zagranicznym na świecie, który w dowód historycznych zasług występował przed Kongresem USA, nie pełniąc funkcji głowy państwa, szefa rządu lub ambasadora (15 listopada 1989 roku). Zbyteczne byłoby tu wyjaśnianie, dlaczego partia rządząca zalicza Stany Zjednoczone do państw, z których zdaniem Polska powinna się szczególnie liczyć, jednak generalnie zakłada ona, że 
zagranica nie ma innego wyboru niż szanowanie każdego wyrazu „woli suwerenna”.

Po drugie, trudno uniknąć wrażenia, że u źródeł ustawy dekomunizacyjnej z 1 kwietnia 2016 roku (Ustawa o zakazie propagowania komunizmu lub innego ustroju totalitarnego przez nazwy budowli, obiektów i urządzeń użyteczności publicznej 2016) leżało przede wszystkim dążenie do zachowania przez Polskę pierwszeństwa w konkurencji, który z narodów Europy Środkowej i Wschodniej położył największe zasługi w walce z dwoma totalitaryzmami. Najprawdopodobniej sprawa nie zyskałaby wysokiej rangi w tej kadencji Sejmu, gdyby nie wojna rosyjsko-ukraińska oraz przyjęcie takiej ustawy przez Radę Najwyższą Ukrainy 9 kwietnia 2015 roku. Innymi słowy, większość parlamentarna postanowiła się nie dać wyprzedzić państwu, które jej zdaniem ma do bycia liderem w tym zakresie słabszy mandat historyczny i moralny. Jednak o ile na Ukrainie usunięcie tysięcy sowieckich nazw topograficznych oraz setek pomników samego Lenina w kontekście toczącej się wojny ma charakter działania narodotwórczego, o tyle w Polsce przypomina raczej „wbicie osikowego kołka” w politykę pamięci Rosji odnośnie do Wielkiej Wojny Ojczyźnianej, na którą władze nie mają żadnego wpływu.

Nowelizacją tej ustawy z 22 czerwca 2017 roku parlament nakazał też likwidację pomników „propagujących ustrój totalitarny”, w tym pomników wdzięczności armii radzieckiej (Ustawa o zmianie ustawy o zakazie propagowania komunizmu lub innego ustroju totalitarnego przez nazwy budowli, obiektów i urządzeń użyteczności publicznej 2017) ${ }^{8}$. Ustawa przecięła dyskusję nad oceną postaci z historii Polski, które, jak np. gen. Zygmunt Berling czy ochotnicy z Brygady im. Jarosława Dą-

\footnotetext{
${ }^{8}$ Co do marszu Armii Czerwonej w latach 1944-1945, to między władzami Polski i Rosji istnieje rozbieżność w kwestii rozumienia umowy z 22 lutego 1994 r. o grobach i miejscach pamięci ofiar wojen i represji. Jej interpretacja i wykonanie przez stronę polską od 2015 r. nie zmieniły się: wolno likwidować tylko pomniki (tzw. pomniki wdzięczności), a nie także miejsca pochówku. Szczątki zwłok żołnierzy wolno przenosić jedynie „w sytuacjach wyjątkowych" na inne cmentarze. Nowością ustawy jest narzucenie obowiązku likwidacji pomników poza cmentarzami. Zob. też Czarnecka 2015.
} 
browskiego w hiszpańskiej wojnie domowej, podjęły decyzje zbyt wieloznaczne, aby można było je skwitować kilkoma zdaniami orzeczenia IPN, iż służyli budowie „totalitarnego” ustroju „stalinowskiego”.

Z kolei ustawa dezubekizacyjna z 16 grudnia 2016 r., ograniczająca emerytury pracownikom sektora bezpieczeństwa w PRL od 22 lipca 1944 do 31 lipca 1990 roku, opierała się na rozwiązaniach najprawdopodobniej (nie została do Trybunału skierowana) niekonstytucyjnych m.in. takich jak: uznanie, że służąc w tym okresie „totalitarnemu państwu” nie wykonywali oni pracy w ogóle, zrównanie odpowiedzialności oficera śledczego, informatyka i sekretarki, odrzucenie przez państwo zobowiązań podjętych wobec pozytywnie zweryfikowanych funkcjonariuszy w roku 1990 (Ustawa o zmianie ustawy o zaopatrzeniu emerytalnym funkcjonariuszy 2016).

Po trzecie, polityka pamięci o antagonistycznych konsekwencjach dała o sobie znać w pozbawieniu twórców Muzeum II Wojny Światowej w Gdańsku możliwości kierowania nim pod hasłem potrzeby „unarodowienia” jego narracji. W tym przypadku rozmiary straty poniesionej na arenie międzynarodowej jeszcze trudno ocenić, bowiem nie wiadomo, jak daleko sięgnie ingerencja nowej dyrekcji w charakter wystawy. Niemniej już dotychczasowe wypowiedzi i działania wskazują na ograniczenie kontekstu międzynarodowego wydarzeń w Polsce, przesunięcie uwagi z losów „zwykłych” ludzi reprezentatywnych dla poszczególnych zbiorowości na postaci bohaterów oraz odebranie wystawie ostatecznego pacyfistycznego przesłania. Końcowy film, ukazujący w negatywnym świetle konflikty zimnej wojny oraz współczesne używanie siły przez mocarstwa do rozwiązywania problemów międzynarodowych, zastąpiono obrazem, mającym na celu wykazanie wyjątkowości polskiego wkładu w latach 1939-1945 oraz nobilitację walki zbrojnej jako moralnie słusznego sposobu osiągania celów.

W ten sposób następuje „powrót” Muzeum do funkcji dydaktycznej, którą instytucje państwowe pełniły do początków procesu pojednania 
między narodami europejskimi po II wojnie światowej: kształtowania zdolności do złożenia ofiary z życia jako swego rodzaju normy obowiązku obywatelskiego w miejsce uczenia o tym, jak uniknąć powtórzenia sytuacji, w których w przeszłości okazywało się to konieczne.

Co więcej, wraz z odwołaniem dyrekcji pod kierunkiem Pawła Machcewicza Muzeum utraciło kolegium programowe, w którym obok profesorów z Polski zasiadali specjaliści z państw czterech głównych zwycięzców II wojny światowej na świecie (m.in. Timothy Snyder i Norman Davies) oraz Izraela (Machcewicz 2017). MKiDN dążyło do wymiany kierownictwa placówki przede wszystkim dlatego, że idea powołania Muzeum była kojarzona z inicjatywą rządu Donalda Tuska. Ta motywacja władz doprowadziła do głębokiego podziału środowiska badaczy dziejów najnowszych w Polsce i osłabienia pozycji polskiej historiografii na arenie międzynarodowej. W lutym 2018 roku zaczą się proces o naruszenie praw autorskich wytoczony obecnej dyrekcji przez poprzednią.

Po czwarte, negatywne skutki mają działania władz w obszarze stosunków polsko-ukraińskich. 22 lipca 2016 roku Sejm, postępując za Senatem, zakwalifikował antypolską akcję OUN-UPA na Wołyniu i w Galicji Wschodniej jako ludobójstwo, przyjmując wspomnianą uchwałę o nadaniu 11 lipca, rocznicy wymordowania mieszkańców wsi Poryck/Pawliwka i kilkudziesięciu innych wsi w 1943 roku, rangi oficjalnego dnia pamięci (Uchwała Sejmu RP w sprawie oddania hołdu ofiarom ludobójstwa dokonanego przez nacjonalistów ukraińskich na obywatelach II Rzeczypospolitej Polskiej w latach 1943-1945 2016).

W późniejszych wypowiedziach prezes PiS, Jarosław Kaczyński, wprost uzależnił dobre stosunki Polski z Ukrainą od przyjęcia przez nią takiej kwalifikacji tych zbrodni. Następnie policja oraz prokuratura okazały się wyjątkowo „nieudolne” w ściganiu sprawców zniszczeń ukraińskich upamiętnień w Polsce poświęconych walkom z lat 1943-1947 oraz aktów mowy nienawiści wobec obywateli Ukrainy, w końcu MSWiA, odpowiedzialne za dotacje dla organizacji mniejszości narodowych, po raz 
pierwszy w III RP zignorowało obchody siedemdziesiątej rocznicy akcji „Wisła” stanowiącej fundament pamięci mniejszości ukraińskiej. Sięgnięcie przez PiS po metody skrajne, aby uzyskać potępienie akcji UPA przez władze w Kijowie, okazało się przeciwskuteczne. Wybrany przez stronę polską sposób działania został na Ukrainie odebrany jako upokarzający i jednoznacznie odrzucony. Z jednej strony był on oparty na przecenie siły atutów, jakimi Polska dysponuje w swej polityce wschodniej, z drugiej - ukraińskie elity doskonale zdają sobie sprawę, że władze Polski stopniowo popadają w izolację w UE, m.in. właśnie z powodu przyłożenia zbytniej wagi do polityki pamięci w ogóle.

Po piąte, nadmierne przydawanie znaczenia „godności” narodowej pchnęło partię rządzącą do konfliktu z sojusznikami: Izraelem i Stanami Zjednoczonymi, wystawiając na ryzyko cały dorobek pracy nad wizerunkiem Polski w czasie II wojny światowej co najmniej od upamiętnienia zbrodni w Jedwabnem w 2001 roku. W nowelizacji ustawy o IPN z 26 stycznia 2018 roku Sejm objął penalizacją i ustanowił sankcję do trzech lat więzienia dla wypowiedzi przypisujących „publicznie i wbrew faktom (...) Narodowi Polskiemu lub Państwu Polskiemu odpowiedzialność lub współodpowiedzialność za popełnione przez III Rzeszę Niemiecką zbrodnie nazistowskie (...) lub za inne przestępstwa stanowiące zbrodnie przeciwko pokojowi, ludzkości lub zbrodnie wojenne lub w inny sposób rażąco pomniejsza[jące] odpowiedzialność rzeczywistych sprawców tych zbrodni” (Ustawa o zmianie ustawy o IPN - KŚŻpNP 2018).

Taka próba przeciwdziałania przez władze występowaniu w mediach za granicą zwrotu „polskie obozy śmierci (zagłady, koncentracyjne)” została odebrana jako wyraz frustracji i rzeczywistej niewiary w skuteczność środków pozytywnych polegających na informowaniu o odpowiedzialności III Rzeszy za Holocaust na ziemiach polskich (a przecież jednocześnie władze stworzyły instytucje mające takich środków właśnie użyć). Projektodawcy argumentowali, że gdyby spenalizowano 
wyłącznie wymieniony zwrot, nie objęto by innych sformułowań obraźliwych dla Polski odnośnie do Holocaustu, których by natychmiast w mediach zaczęto używać, stąd wprowadzono określenie o jak najszerszym znaczeniu. Ale od początku powinno być dla projektodawców powinno być oczywiste, że poza Polską nikt tego przepisu nie wykona, wydając jej podejrzanych, zatem ustanowią prawo niewykonalne.

Powstało wrażenie, że władze chcą ukryć takie przypadki jak w Jedwabnem oraz ograniczają wolność badań naukowych dla historyków zza zagranicy, a tym bardziej dla krajowych. Wprawdzie chronił ich przepis wyłączający karalność za takie wypowiedzi popełnione „w ramach działalności artystycznej lub naukowej”, ale cóż może przeszkodzić sądowi, jeśli kolejną wypowiedź Jana Tomasza Grossa zdefiniuje jako „publicystyczną”. Zagrożenia dotyczyły także badaczy, którzy używają terminu „obóz koncentracyjny” wobec zbrodni popełnionych przez funkcjonariuszy państwa polskiego, polegających na stworzeniu warunków do śmierci z chorób, głodu i wycieńczenia więźniów politycznych w Berezie Kartuskiej (1934-1939), oficjalnie nazywanej „miejscem odosobnienia”, oraz w Świętochłowicach-Zgodzie (w roku 1945; głównie dla Niemców i Ślązaków) i Jaworznie (1945-1949; od roku 1947 dla Ukraińców i Łemków deportowanych w ramach akcji „Wisła”), oficjalnie nazywanych „obozami pracy”.

Nowelizacja ustawy o IPN spotkała się z jednoznaczną krytyką Izraela i Stanów Zjednoczonych. Już w czerwcu 2018 roku ryzyko wynikające z ewentualnego wycofania się Stanów Zjednoczonych z dodatkowych zobowiązań na rzecz obrony Polski wprowadzonych po wybuchu wojny rosyjsko-ukraińskiej skłoniło władze do zawarcia swego rodzaju ugody z Izraelem i kolejnej zmiany ustawy anulującej zapisy sprzed kilku miesięcy ograniczające swobodę badań i wypowiedzi na temat Holocaustu. Być może w związku z tym, że rząd Niemiec postarał się ułatwić

9 O obozach po II wojnie światowej zob. reportaż historyczny: Łuszczyna 2017. 
sytuację władz Polski po wybuchu kryzysu, deklarując pełną odpowiedzialność za Holocaust, na początku roku 2018 rząd premiera Morawieckiego nie podnosił żądania reparacji za zniszczenia wywołane okupacją w latach 1939-1945. Wysunięto je jeszcze w sierpniu 2017 roku, być może głównie po to, aby mieć „kartę przetargową” w rozmowach z Niemcami, od których zdania w dużej mierze zależy ewentualne zastosowanie przez UE sankcji wobec Polski za „naruszanie praworządności” oraz w związku z tym ograniczenie wypłat krajom członkowskim z funduszy spójności w planowanym budżecie organizacji na lata 20212027. Jednak i w tej kwestii nie można były wykluczyć, że władze, nagłaśniając żądanie reparacji publicznie, na dłuższą metę zamierzały okazać nieustępliwość.

Inaczej niż partnerów zachodnich rządzący traktowali natomiast Ukrainę. O tym, że po odrzuceniu przez Radę Najwyższą wspomnianej uchwały dotyczącej ludobójstwa z 22 lipca 2016 roku, czynniki rządowe przestały wierzyć w skuteczność polityki pamięci wobec Ukrainy, ale nie zrezygnowały z wykorzystania tego tematu w polityce wewnętrznej, świadczy przegłosowanie przez PiS w Sejmie wniosku klubu Kukiz'15, aby „przy okazji” wypowiedzi na temat Holocaustu w ustawie z 26 stycznia 2018 roku spenalizować i zagrozić karą do trzech lat więzienia także zaprzeczanie zbrodniom „ukraińskich nacjonalistów i członków ukraińskich formacji kolaborujących z Trzecią Rzeszą Niemiecką”. Nie leżało to pierwotnie w ich planach, lecz po dyskusji w Sejmie większość rządowa poparła taki wniosek najprawdopodobniej dlatego, aby w obronie „godności” Polaków nie dać się przelicytować drugiej partii prawicowej.

Przepis, reklamowany przez Kukiz'15 jako „zakaz propagowania banderyzmu”, najpierw szeroko określa, iż zbrodniami tymi były „czyny popełnione przez ukraińskich nacjonalistów w latach 1925-1950, polegające na stosowaniu przemocy, terroru lub innych form naruszania praw człowieka wobec jednostek lub grup ludności”, a następnie precyzuje: „[z]brodnią ukraińskich nacjonalistów i członków ukraińskich formacji 
kolaborujących z Trzecią Rzeszą Niemiecką jest również udział w eksterminacji ludności żydowskiej oraz ludobójstwie na obywatelach II Rzeczypospolitej na terenach Wołynia i Małopolski Wschodniej” (Ustawa o zmianie ustawy o IPN - KŚŻpNP (2018).

W ostatnim zdaniu, a także w wypowiedzi premiera Morawieckiego z 13 lutego 2018 roku wskazującej na falę pogromów antyżydowskich w czasie powstania Bohdana Chmielnickiego na Ukrainie jako wydarzenie poprzedzające Holocaust (Trojan 2018), widać próby przekonania Izraela i międzynarodowej opinii publicznej do tezy, iż Polska najlepiej w Europie Środkowej i Wschodniej dba o prawdę na temat Zagłady, popełniane kosztem reputacji wschodniego sąsiada. Władze Ukrainy rzeczywiście od roku 1991 nie oceniły antysemickiej propagandy OUN oraz pogromów antyżydowskich z roku 1941 w zachodniej części kraju, ale ten rodzaj „troski” Sejmu o żydowskich obywateli II RP, biorąc pod uwagę jednoczesne wprowadzenie penalizacji wypowiedzi dotyczących udziału Polaków w Holocauście, nie mógł być wiarygodny.

O tym, że władze polityki pamięci wobec Ukrainy już faktycznie nie prowadziły, świadczyło też to, że nawet nie zadbały, aby przepisem wyłączającym spod karalności wypowiedzi twórców i naukowców objąć także tych, którzy zajmują się zbrodniami ukraińskimi. Ukraiński IPN wykorzystał kryzys wokół Polski i ogłosił, iż nie dopuści do kolejnego wyjazdu do niej uczestników Forum Historyków, powołanego wspólnie z IPN w roku 2016, a dalsze prace tego gremium mogą się toczyć wyłącznie na Ukrainie (Zajawa Ukrainśkoho instytutu nacijonalnoji pam’jati). Oznaczało to najgłębszy kryzys dialogu specjalistów polskich i ukraińskich co do przeszłości z lat 1939-1947 prowadzonego nieprzerwanie od roku 1991. Równie złe wrażenie na Ukrainie wywarło to, że gdy władze Polski zdecydowały się w końcu wycofać zapisy w ustawie dotyczące Holocaustu, nikt z rządzących nawet nie zająknął się w Sejmie co do potrzeby poprawienia zapisów odnoszących się do ukraińskiego ruchu nacjonalistycznego. 
W końcu po szóste - jak się wydaje, po dwu latach od przejęcia władzy przystąpiono do rozwiązania kwestii, o której pamięć najbardziej dzieli społeczeństwo polskie, katastrofy smoleńskiej. W lecie 2017 roku prezes PiS zapowiedział, iż 96. miesięcznica 10 kwietnia 2018 roku będzie najprawdopodobniej ostatnią. Na przełomie 2017 i 2018 wojewoda mazowiecki w trybie ustawy dekomunizacyjnej nadał fragmentowi Trasy Łazienkowskiej imię Lecha Kaczyńskiego, nowy premier pozbawił funkcji szefa MON głównego zwolennika teorii zamachu, Antoniego Macierewicza, ruszyły prace nad ustanowieniem pomnika ofiar w reprezentacyjnym miejscu na placu Marszałka Józefa Piłsudskiego w pobliżu Grobu Nieznanego Żołnierza.

Kroki te raczej zapowiadały ograniczenie napięcia wokół tej kwestii. Jednak intencje obozu władzy nie były do końca jasne. Zachowanie w MON Podkomisji ds. Ponownego Zbadania Wypadku Lotniczego pod kierownictwem byłego ministra, pomimo wielokrotnej kompromitacji powoływanych przez niego ekspertów, mogło świadczyć tak o dalszym dążeniu do udowodnienia teorii zamachu, jak o próbie „ratowania twarzy” wobec wyczerpania możliwości wykazania sprawstwa rosyjskiego. W każdym razie kierownictwo PiS nie zdecydowało się na ostateczną rezygnację z jednego z głównych narzędzi mobilizacji niezadowolonych. Być może dlatego, że autentyczna trauma Jarosława Kaczyńskiego i jego otoczenia z roku 2010 najlepiej uwiarygodniała w oczach opinii publicznej romantyczno-tradycjonalistyczną koncepcję polskości leżącą u podłoża ich martyrologiczno-heroicznej polityki pamięci.

Polska polityka pamięci na tle Europy Środkowej i Wschodniej

Źródeł hipertrofii polityki pamięci w Polsce proponuję szukać przede wszystkim w cechach jej kultury historycznej. Ta pierwsza nie jest w Europie Środkowej i Wschodniej przypadkiem odosobnionym. Obecnie ewolucję w kierunku unifikacji pamięci i tożsamości oraz zapewnienia sobie 
przez partie prawicy ciągłości rządów poprzez zniesienie mechanizmów kontrolnych demokracji liberalnej oprócz Polski najbardziej widać w trzech państwach regionu. Przede wszystkim w Rosji, gdzie przekroczyła ona już „próg” ewolucji od demokracji do autorytaryzmu, zwłaszcza od powrotu Putina na funkcję prezydenta w roku 2012. Ponadto dotyczy Węgier od powstania rządu Fideszu premiera Viktora Orbana w roku 2010 oraz od kilku lat także Serbii. Ewolucja polityki serbskiej weszła w nowy etap po zwycięstwie w pierwszej turze wyborów prezydenckich w kwietniu 2017 roku Aleksandra Vučicia, premiera od roku 2014. Jest to polityk z dawnej Serbskiej Partii Radykalnej, skrajnie nacjonalistycznej, przejściowo koalicjantki prezydenta Slobodana Miloševicia z okresu wojen w Bośni i Hercegowinie oraz Kosowie w latach dziewięćdziesiątych. Od roku 2012 stoi na czele centroprawicowej Serbskiej Partii Postępowej (powstałej z rozłamu u radykałów) i prowadzi politykę integracji Serbii z UE, jednak od poprzednich faz swojej kariery politycznej się bynajmniej nie odcina. Politykę akcesji traktuje Vučić, podobnie jak Orban i Kaczyński, w kategoriach korzyści gospodarczych, bowiem UE jawi się jako jedyny gracz międzynarodowy, który jest gotowy wesprzeć modernizację infrastrukturalną Serbii.

W historii Europy Środkowej i Wschodniej te cztery narody i państwa coś istotnego połączyło. Kultury polska i węgierska mają wyraźnie charakter postszlachecki. Kultura narodowa Rosji nie jest aż tak silnie oparta na tradycjach elit społecznych, jednak i w niej istotną rolę odgrywają symbole arystokratyczne oraz dynastyczne. Podobnie w Serbii, której kultura ma nawet przede wszystkim pierwiastki ludowe, ale w związku z upadkiem monarchii dopiero w roku 1945, rządami Tity i Miloševicia, występuje silniejsza niż w Polsce i na Węgrzech tradycja rządów jednostkowych. Ponadto, co najważniejsze, wszystkie te cztery narody mają liczne mniejszości narodowe, „odcięte” od ich państw granicami wskutek porażek wojennych w XX w. O ile Polacy i Węgrzy czują się dziedzicami regionalnych „cywilizacji” ziemiańskich dominujących 
w Europie Środkowej do roku 1918, o tyle Rosjanie i Serbowie postrzegają siebie jako narody, które poniosły w XX w. największe koszty budowy państw federalnych. W ich ujęciu utworzenie ZSRR i Jugosławii miało na celu z jednej strony zapewnienie im samym zjednoczenia w jednym państwie, z drugiej - wsparcie otaczających ich narodów słowiańskich, zagrożonych przez „imperializm” Zachodu oraz dążenia asymilacyjne przeważnie niesłowiańskich, obcych” kulturowo, sąsiadów. Nie należy także zapominać, iż upadek ZSRR otworzył w Rosji drogę do oparcia polityki pamięci państwa na tradycjach imperium z okresu od Piotra I do Mikołaja II.

W historii tych czterech narodów wyraźniej zaznaczyły się motywy mesjanistyczne, reprezentowane przez ich silnie zetnicyzowane kościoły i cerkwie (na Węgrzech stosunkowo w najmniejszym stopniu), rozwinięte w literaturze romantycznej i podtrzymane w koncepcjach politycznych w XX w. (np. w polskim prometeizmie). W przypadku Polski i Węgier do XVIII w. była to misja obrony cywilizacji zachodniej, zaś w XX w. próby „odbudowy” związków państwowych w granicach ich ziem „historycznych” na zasadzie federacji czy autonomizacji ziem „kresowych”. Misja Rosji polegała na odgrywaniu roli centrum prawosławia i Słowiańszczyzny, po upadku Bizancjum w roku 1453 jedynego depozytariusza prawowitego chrześcijaństwa i idei uniwersalnego cesarstwa. W roku 1917 misja ta została „zastąpiona” misją obalenia kapitalizmu i ustanowienia światowych rządów proletariatu. W końcu misja Serbii polegała na obronie wiary i kultury chrześcijańskiej przed naporem islamu i miała charakter najściślej związany z Cerkwią oraz kultem kanonizowanych przedstawicieli średniowiecznej dynastii Nemaniczów. W XIX wieku, podobnie jak w Rosji, nabrała charakteru misji wyzwoleńczej Słowian południowych spod panowania tureckiego i habsburskiego, a dziś jest przywoływana głównie w związku z pretensjami do przywrócenia rządów w Kosowie. 
Ostatecznie nie wydaje się dziełem przypadku, że rządy silnego przywódcy i koncepcja zunifikowanego narodu kulturowego najsilniej ostatnio doszła do głosu właśnie w tych czterech państwach regionu. W polityce dwu większych z nich - Rosji i Polski - nastąpił także, budowany w oparciu o wspomniane mity historyczne, powrót do misji w wymiarze międzynarodowym. O ile władze Rosji przypisują jej dziś rolę obrończyni Europy i Bliskiego Wschodu przed z jednej strony zmilitaryzowaną i łamiącą prawo międzynarodowe potęgą Stanów Zjednoczonych, z drugiej - zalewem „zachodniej” kultury masowej, stylów życia i permisywizmu obyczajowego, o tyle władze Polski (od roku 2015 w zasadzie zgodne z drugą z tych motywacji władz Rosji) podejmują próbę rekonstrukcji UE w kierunku konfederacyjnej „Europy narodów” oraz szukają sojuszników w amerykańskich Republikanach oraz brytyjskich konserwatystach epoki Brexitu. Z jednej strony także w innych państwach Europy Środkowej i Wschodniej tendencje antyglobalizacyjne przybrały formę „powrotu” do dwudziestowiecznego państwa narodowego, z drugiej - opinia publiczna państw „starej” UE straciła wyrozumiałość dla „nowych” członków i nie będzie starała się, najprawdopodobniej z wyjątkiem Niemiec, o to, aby uczestniczyli oni w kolejnym etapie integracji.

Jednak temu „scenariuszowi”, pesymistycznemu z punktu widzenia bezpieczeństwa i współpracy w Europie, można przeciwstawić argumenty wskazujące na „wypłukiwanie” się źródeł scharakteryzowanej w tekście polityki pamięci i tożsamości. Na przykładzie Polski można sądzić, iż, po pierwsze, po przetoczeniu się przez region obchodów stulecia wydarzeń z lat 1917-1921 nasycenie infrastrukturą pamięci chroniącej tożsamość narodową w postaci świąt, muzeów, instytucji promocyjnych i sankcji karnych obejmie już wszystkie budzące emocje problemy z historii najnowszej.

Przecież trudno sobie wyobrazić, że poparcie społeczne zyskają jeszcze projekty osobnych muzeów np. rewolucji lat 1905-1906, zamachu majowego w roku 1926, wyborów czerwcowych w roku 1989 czy tragedii 
smoleńskiej w roku 2010. Po drugie, nieosiągnięcie przez PiS w okresie jego rządów żadnego z celów polityki pamięci na arenie międzynarodowej skłoni następny rząd do zdjęcia ich z agendy polityki zagranicznej. Wtedy polityka pamięci „zejdzie” - tak jak to jest już od kilku dekad w Europie Zachodniej - z poziomu państwowego na samorządowy. Miasta będą dbały o pamiątki kultury, ale przede wszystkim dlatego, aby zarabiać na turystach albo wygrywać konkursy na Europejską Stolicę Kultury. Po trzecie, w ciągu dwudziestu lat ostatecznie w Europie Środkowej i Wschodniej odejdzie pokolenie, które albo osobiście pamięta II wojnę światową, albo ukształtowało się w atmosferze niezaleczonych ran po niej, represji stalinowskich i najostrzejszej fazy konfrontacji zimnowojennej.

Jest też parę niewiadomych co do tego, czy ten optymistyczny „scenariusz” się spełni. Po pierwsze, w jakim kierunku przebiegnie rozwój mediów? Czy uda się powstrzymać proces zamykania się ludzi w „bańkach internetowych” oraz zalewu mowy nienawiści bez ograniczenia wolności słowa? Czy przeminie popularność „gotyckich” gier komputerowych, która skłania młodzież do utożsamiania się w historii z bohaterami walczącymi contra mundum (jakich w Polsce w okresie tuż powojennym mieliśmy szczególnie wielu)? I, co dla tego regionu najważniejsze, czy w Rosji nie tylko państwo, ale także społeczeństwo obywatelskie wydobędzie się z impasu?

W każdym razie już teraz warto pomyśleć o upamiętnieniu być może ostatniego ważnego wydarzenia z „wieku skrajności”, o którym dziś nikt prawie nie wspomina - śmierci z głodu w latach 1941-1945 co najmniej pół miliona jeńców Armii Czerwonej w obozach niemieckich na ziemiach polskich (Jeńcy sowieccy na ziemiach polskich $w$ czasie II wojny światowej 2015). Zwłaszcza gdyby to zrobiono bez wspomnianych zmian w Rosji, byłby to budujący akt zmiany kryteriów polskiej polityki pamięci - z partykularnych na uniwersalne. 
Bibliografia

Bakuła B. (2006), Kolonialne i postkolonialne aspekty polskiego dyskursu kresoznawczego (zarys problematyki), „Teksty Drugie” nr 6 Bez taryfy ulgowej. Dorobek naukowy i edukacyjny Instytutu Pamięci Narodowej 200o-2010 (2012), (red.) A. Czyżewski, Nowinowski S.N., Stobiecki R., Żelazko J., IPN - KŚZpNP, Łódź

Czarnecka D. (2015), „Pomniki wdzięczności” Armii Czerwonej w Polsce Ludowej i w III Rzeczypospolitej, IPN - KŚZpNP, Warszawa

Dalej jest noc. Losy Żydów w wybranych powiatach okupowanej Polski (2018), (red.) Engelking B., Grabowski J, t. 1-2, Centrum Badań nad Zagładą Żydów, Warszawa

Dudek A. (2011), Instytut. Osobista historia IPN, Czerwone i Czarne, Warszawa

Engelking B. (2011), Jest taki słoneczny dzień... Losy Żydów szukajacych ratunku na wsi polskiej 1942-1945, Stowarzyszenie Centrum Badań nad Zagładą Żydów, Warszawa

Fikus D. (1988), Pseudonim „Łupaszka”. Z dziejów V Wileńskiej Brygady Śmierci i mobilizacyjnego ośrodka Wileńskiego Okręgu AK, Most, Warszawa

Gawin: Instytut Solidarności i Męstwa wprowadzi polskie źródła do światowej historiografii (2018), „Gazeta Prawna” 14 lutego, http:// kultura.gazetaprawna.pl/artykuly/1104350,minister-gawin-o-instytut-solidarnosci-i-mestwa.html

Grabowski J. (2011), JUDENJAGD. Polowanie na Żydów, 1942-1945.

Studium dziejów pewnego powiatu, Stowarzyszenie Centrum Badań nad Zagładą Żydów, Warszawa

Instytut Pileckiego, strona internetowa, https://obnt.pl/pl/ Jarska N. (2015), Kobiety z marmuru. Robotnice $w$ Polsce $w$ latach 1945-196o, IPN - KŚZpNP, Warszawa 
Jeńcy sowieccy na ziemiach polskich $w$ czasie II wojny światowej (2015), (red.) Wojtkowiak J., Centrum Polsko-Rosyjskiego Dialogu i Porozumienia, Warszawa

Koczwańska-Kalita D. (2015), (Nie)chciane dziecko III RP. Instytut Pamięci Narodowej 20oo-201o. Geneza, funkcjonowanie, kontekst spoteczny i politycznyArcana, Kraków

Kozubal M. (2018), IPN ściga SS-manów, „Gazeta Wyborcza”, dodatek „Historia”, 14 stycznia, http://www.rp.pl/Historia/301149967-IPNsciga-SS-manow.html

Krzemiński A., Thiriet D. (2015), Powstanie warszawskie. Ruiny twierdzy, w: Polsko-niemieckie miejsca pamięci, (red.) Traba R., Hahn H.H., (współpr.) Górny M., Kończal K., t. 2: Wspólne/Oddzielne, Scholar, Warszawa

Libionka D. (2017), Zagłada Żydów w Generalnym Gubernatorstwie: zarys problematyki, Państwowe Muzeum na Majdanku, Lublin Łuszczyna M. (2017), Mała zbrodnia. Polskie obozy koncentracyjne, Znak Horyzont, Kraków

Machcewicz P. (2017), Muzeum, Znak Horyzont, Kraków

Miller A. (2012), Istoriczieskaja politika $w$ Wostocznoj Jewropie naczata XXI $w$., w: Istoriczieskaja politika $w X X I w$., (red.) Miller A., Lipman M., Nowoje Litieraturnoje Obozrienije, Moskwa

Moroz A. (2016), Między historiq a pamięciq̨. Konflikt pamięci zbiorowych Polaków i Biatorusinów na przykładzie postaci Romualda Rajsa „Burego”, IPN - KŚZpNP, Warszawa

Pamięć i odpowiedzialność (2005), (red.) Kostro R., Merta T., Gawin D., Ośrodek Myśli Politycznej, Kraków; Centrum Konserwatywne, Wroclaw

Pamięć i polityka historyczna. Doświadczenia Polski i jej sąsiadów (2008), (red.) Nowinowski S.M., Pomorski J., Stobiecki R., IPN KŚZpNP, Łódź 
Pilawski K. (2015), Zrobimy z Polski druga Bawarię, „Tygodnik Przegląd” 16 listopada, https://www.tygodnikprzeglad.pl/zrobimy-zpolski-druga-bawarie

Płeć buntu. Kobiety $w$ oporze społecznym i opozycji $w$ Polsce $w$ latach 1944-1989 na tle porównawczym (2014), (red.) Jarska N., Olaszek J., IPN - KŚZpNP, Warszawa

Podwójnie wyklęty (2017), reż. Szakalicka E. [film]

Putin W. (2009), List Putina do Polaków - petna wersja, „Gazeta Wyborcza” 31 sierpnia, http://wyborcza.pl/1,75399,6983945,List_Putina_do_Polakow pelna_wersja.html

Rokicki P. (2015), Glinciszki i Dubinki. Zbrodnie wojenne na Wileńszczyźnie $w$ połowie 1944 roku i ich konsekwencje we wspótczesnych relacjach polsko-litewskich, IPN - KŚZpNP /ISP PAN, Warszawa Szpytma M. (2009), The Risk of Survival. The Rescue of the Jews by the Poles and the Tragic Consequences for the Ulma Family from Markowa, IPN, Warszawa-Kraków

Transitional Justice in Eastern Europe and the Former Soviet Union. Reckoning with the Communist Past (2009), (ed.) Stan L., Routledge, New York

Trojan M. (2018), Morawiecki zacytowat rabina, Kresy.pl, https:// kresy.pl/wydarzenia/morawiecki-zacytowal-rabina-chmielnickizbrodniarz-hitler-himmler-ukraincy-oburzeni-video/

Uchwała Sejmu RP w sprawie oddania hołdu ofiarom ludobójstwa dokonanego przez nacjonalistów ukraińskich na obywatelach II Rzeczypospolitej Polskiej w latach 1943-1945 (2016), http://dziennikustaw.gov.pl/mp/2016/726/1

Ustawa o Instytucie Solidarności i Męstwa (2017), http://www.infor.pl/akt-prawny/DZU.2017.241.0002303,ustawa-o-instytucie-solidarnosci-i-mestwa.html

Ustawa o zakazie propagowania komunizmu lub innego ustroju totalitarnego przez nazwy budowli, obiektów i urządzeń użyteczności 
publicznej (2016), http://prawo.sejm.gov.pl/isap.nsf/donload.xsp/ WDU20160000744/U/D20160744Lj.pdf

Ustawa o zmianie ustawy o IPN - KŚZpNP oraz niektórych innych ustaw (2016), http://prawo.sejm.gov.pl/isap.nsf/download.xsp/W DU20160000749/T/D20160749L.pdf

Ustawa o zmianie ustawy o IPN - KŚŻ́NP (2018), http://www.dziennikustaw.gov.pl/du/2018/369

Ustawa o zmianie ustawy o zakazie propagowania komunizmu lub innego ustroju totalitarnego przez nazwy budowli, obiektów i urządzeń użyteczności publicznej (2017), http://prawo.sejm.gov.pl/isap.nsf/ download.xsp/WDU20170001389/O/D20171389.pdf

Ustawa o zmianie ustawy o zaopatrzeniu emerytalnym funkcjonariuszy (2016), http://www.dziennikustaw.gov.pl/du/2016/2270/1

Ustawa o Instytucie Pamięci Narodowej - Komisji Ścigania Zbrodni przeciw Narodowi Polskiemu (1998), http://prawo.sejm.gov.pl/isap. nsf/download.xsp/WDU19981551016/O/D19981016.pdf

Uzasadnienie (2015), Rządowe Centrum Legislacyjne, https://legislacja.rcl.gov.pl/docs//2/52748/52762/52763/dokument93095.pdf Wokót Jedwabnego (2002), (red.) Machcewicz P., Persak K., t. I: Studia, t. II: Dokumenty, IPN - KŚZpNP, Warszawa

Wolff-Powęska A. (2011), Brzemię i uwolnienie. Niemcy wobec nazistowskiej przeszłości (1945-2010), Zysk i S-ka, Poznań

Wolfrum E. (1999), Geschichtspolitik in der Bundesrepublik Deutschland. Der Weg zur bundesrepublikanischen Erinnerung 19481990, Wissenschaftliche Buchgesellschaft, Darmstadt

Zajawa Ukrainśkoho instytutu nacijonalnoji pam’jati, http://www. memory.gov.ua/news/zayava-ukrainskogo-institutu-natsionalnoipam-yati-shchodo-nemozhlivosti-prodovzhennya-roboti-u Žižek S. (2005), The Two Totalitarianism, "London Review of Books" Vol. 27, No. 6 